\title{
Effects of costimulation on intrahepatic immunopathogenesis in patients with chronic $\mathrm{HBV}$ infection
}

\author{
Bei Zhong • Mao Ping Huang • \\ Guo Qing Yin · Xiang Gao
}

Received: 25 April 2013/Revised: 29 October 2013/Accepted: 21 November 2013/Published online: 14 December 2013

(C) The Author(s) 2013. This article is published with open access at Springerlink.com

\begin{abstract}
Objective Chronic HBV infection can lead to "immune tolerance" in asymptomatic carriers (ACs), "immune injury" in active chronic hepatitis $(\mathrm{ACH})$ patients or "immune abnormality" in cirrhosis (Cir) and hepatocellular carcinoma (HCC) patients. Previous investigations reported that chronic hepatitis presented abnormal expression of costimulatory molecules. We investigated the costimulation profile in the liver of ACs and patients with $\mathrm{ACH}$, Cir and HCC.

Methods Patients with ACH, Cir and HCC, ACs and normal controls were recruited into the present study. The costimulation profiles and cytokines in the liver of patients were investigated by Western blotting, immunohistochemistry and real-time quantitative PCR. Correlations between serum alanime aminotransferase (ALT) levels,
\end{abstract}

Responsible Editor: Kumar Visvanathan.

Electronic supplementary material The online version of this article (doi:10.1007/s00011-013-0691-3) contains supplementary material, which is available to authorized users.

\section{B. Zhong $\cdot$ M. P. Huang}

The Affiliated Qingyuan Hospital, Jinan University Medical School, Yinquannan Road, Qingyuan 511500, Guangdong, China

B. Zhong

e-mail: zhongbei62@sina.com

M. P. Huang

e-mail: ping660815@126.com

\section{G. Q. Yin $(\bowtie)$}

Department of Infectious Disease, Nanjing Zhong-Da Hospital, Southeast University School of Medicine, 87 Ding jia Qiao,

Nanjing 210009, Jiangsu, China

e-mail: Yin.GQ@hotmail.com necroinflammation scores, cytokines and costimulatory proteins were assessed.

Results The ACs presented decreased inflammatory and increased inhibitory costimulation, which was negatively correlated with inflammatory costimulatory proteins and ALT, whereas the ACH patients exhibited increased inflammatory costimulation and decreased inhibitory costimulation, which was correlated with increased ALT. The Cir patients showed both increased inhibitory and inflammatory costimulation. The HCC patients exhibited both decreased inhibitory and inflammatory costimulation. Conclusion Costimulation participates in intrahepatic immune responses, and plays important roles in immune tolerance, immune injury and immune abnormalities in patients with chronic HBV infection.

Keywords Chronic hepatitis B infection .

Costimulatory molecule .

Intrahepatic immunopathophysiology · Immune tolerance

G. Q. Yin

The Second Affiliated Hospital, Southeast University School of Medicine, 1-1 Zhongfu Road, Nanjing 210003, Jiangsu, China

X. Gao $(\bowtie)$

MOE Key Laboratory of Model Animal for Disease Study, Model Animal Research Center, Nanjing University, Xuefu Road, Pukou District, Nanjing 210061, Jiangsu, China e-mail: gaoxiang@nju.edu.cn 


$\begin{array}{ll}\text { Abbreviations } \\ \text { ACs } & \text { Asymptomatic carriers } \\ \text { ACH } & \text { Active chronic hepatitis } \\ \text { ALT } & \text { Alanime aminotransferase } \\ \text { CHB } & \text { Chronic HBV infection } \\ \text { Cir } & \text { Cirrhosis } \\ \text { CTLA-4 } & \text { Cytotoxic } T \text {-lymphocyte antigen } 4 \\ \text { DCs } & \text { Dendritic cells } \\ \text { HBV } & \text { Hepatitis B virus } \\ \text { HCC } & \text { Hepatocellular carcinoma } \\ \text { HD } & \text { Healthy donors } \\ \text { ICAM-1 } & \text { Intercellular adhesion molecule-1 } \\ \text { PD1 } & \text { Programmed cell death -1 } \\ \text { TB } & \text { Total bilirubin }\end{array}$

\section{Introduction}

Infection with hepatitis B virus (HBV) is a common cause of chronic hepatitis. Approximately 350 million people worldwide are chronically infected with HBV [1, 2]. Because HBV is not usually cytopathogenic by itself, chronic HBV infection (CHB) is a dynamic state of interaction between the virus, hepatocytes and the host's immune system. The natural course of CHB is generally divided into three phases, namely the immune-tolerant phase, the immune clearance phase and the residual or inactive phase. In the immune-tolerant phase, subjects with HBV infection are known as asymptomatic carriers (ACs), presenting persistent immune tolerance against HBV antigens but no evidence of hepatitis [2]. As the immune-tolerant phase changes to the immune clearance phase, patients suffer from intrahepatic inflammatory activity and hepatitis flare. However, these inflammatory responses do not clear HBV in hepatocytes. Persistent HBV reproduction and inflammatory reaction in the liver result in progressive liver disease. Patients with progressive liver diseases present a spectrum of diseases ranging from active chronic hepatitis $(\mathrm{ACH})$, through cirrhosis (Cir) to hepatocellular carcinoma (HCC). ACH patients exhibit "immune injury" and display active hepatitis, and Cir or HCC patients present "immune abnormalities" $[1,2]$. Finding the distinct immune status and investigating the immunopathophysiological differences between immune tolerance, immune injury and immune abnormalities may clarify the immune mechanism of CHB.

The innate and adaptive immune responses induce liver diseases in CHB patients. Both immune regulatory factors and immune cells participate in the clearing of virus components, such as costimulatory factors, cytokines, dendritic cells (DCs), HBV-specific effector $\mathrm{T}$ cells, regulatory $\mathrm{T}$ cells, non-virus-specific lymphocytes, natural killer cells and $\mathrm{B}$ cells. However, the immune responses are extremely complex and only partially understood [3]. Costimulatory proteins, acting as signal peptides, contribute to signal transference among immune cells, and are functional markers of immune cells. When clearing a virus, the viral antigenic peptides are first processed by antigen-presenting cells, mainly DCs, and are bound by MHC II or MHC I complexes in DCs. This binding contributes to DC maturation. The matured DCs are marked by $\mathrm{CD}^{2} 3^{+}, \mathrm{CD} 80^{+}$and $\mathrm{CD}^{+} 6^{+}$. Subsequently, clonally distributed T-cell antigen receptors on naive $\mathrm{T}$ cells capture the viral antigenic peptide-MHC II or MHC I complexes on matured DCs, and $\mathrm{CD} 28$ on $\mathrm{T}$ cells binds with CD80/CD86 on DCs. This process induces expansion and differentiation of clonal $\mathrm{T}$ cells and translates naive $\mathrm{T}$ cells into functional $\mathrm{T}$ cells. In contrast, cytotoxic T-lymphocyte antigen 4 (CTLA-4) on $\mathrm{T}$ cells, acting as an inhibitory factor, negatively regulates the CD28/CD80/CD86 pathway and inhibits T-cell activity. Finally, the functional $\mathrm{T}$ cells activate $\mathrm{B}$ cells and other immune cells, resulting in high expression of CD40 and intercellular adhesion molecule1 (ICAM-1) and inducing secretion of inflammatory cytokines [4-9]. In short, costimulation regulates the immune responses.

Various authors have demonstrated that expression of costimulatory molecules is abnormal in chronic hepatic diseases and viral hepatitis and that abnormal costimulation contributes to immunopathogenesis in liver diseases [4-9]. Nevertheless, their studies have obvious limitations. Firstly, they investigated CHB immunopathophysiology on costimulation signal pathways using animal experiments $[4,6]$. However, the resulting model of HBV infection has not reproduced the whole disease spectrum of humans, including ACs and $\mathrm{ACH}$, Cir and HCC patients. CHB immunopathophysiology must be demonstrated in human liver obtained from the whole disease spectrum. Secondly, the immune tolerance in ACs is a distinct immune state, and its immunopathophysiology in peripheral blood is only partly understood [10], but the intrahepatic costimulation profile has not been investigated. Finally, the liver is an immune-tolerant organ, in which apoptosis and degeneration of functional immune cells take place, resulting in intrahepatic immune suppression [11]. In previous papers, different states of immunopathophysiology between the liver and peripheral blood were defined as "immune compartmentalization", which was found in investigations on animals and humans [11-14]. Costimulatory factor mRNA and costimulation-positive cells were detected in liver and peripheral blood of patients [15, 16], but costimulatory protein in human liver was not studied. In fact, the profile of costimulatory proteins in the liver of 
patients, and not their peripheral blood, exhibits the actual immunopathophysiology of CHB.

We hypothesized that intrahepatic costimulation in ACs and in $\mathrm{ACH}, \mathrm{Cir}$ and $\mathrm{HCC}$ patients was different and that the distinct costimulation profiles might contribute to the intrahepatic immunopathophysiology. Therefore, it was necessary to directly detect costimulatory proteins in the liver of patients.

\section{Materials and methods}

Liver samples and patients

Patients and normal controls, namely ACs, ACH, Cir and HCC patients and healthy donors (HDs), were recruited from January 7, 2002 to June 5, 2006 at four hospitals in Jiangsu Province, China: the Second Affiliated Hospital, Southeast University Medical School; the Surgery Department of the First People's Hospital of Huai' an City; the Liver Transplantation Center of the First Affiliated Hospital, Nanjing Medical University; and the Surgery Department of the People's Hospital of Tai' xing City. AC, $\mathrm{ACH}$, Cir and HCC were defined according to the criteria reported by Lok et al. [17]. The liver tissues were obtained from liver transplantations, surgical operations and biopsies. This research was carried out in accordance with the Declaration of Helsinki (2000) of the World Medical Association. The plan was approved by the Health Office of Jiangsu provincial government, the Health Office of Nanjing municipal government and all the hospital ethics committees. All the patients or the immediate family members of liver donors signed informed consent documents.

Negative $\mathrm{HBeAg}$ patients generally have a predominance of precore and/or basal core promoter HBV mutations that are hence either unable to express or express low levels of $\mathrm{HBeAg}$. These HBV mutations might activate various immune responses in the host, and eventually result in fulminant hepatitis [30]. In order to avoid the influence of precore and the basal core promoter mutations, negative HBeAg patients were excluded from the present study.

Antibodies and reagents

Antibodies for CD83 (H-198, SC-20083) and ICAM-1 (H108, SC-7891) and positive proteins for CD80 (separated Ramos cell) and CD86 (separated Jurkat cell) were purchased from Santa Cruz Biotechnology Inc. Antibodies for CD40 (BWC02, AF632), CD28 (ADS013091, AF-342PB), CTLA-4 (AF-386-BP), CD80 (AAE02, AF140), CD86 (AAE01, AF-141-NA) and $\beta$-actin and standard proteins, namely recombinant human CD80 protein (140-
Table 1 Working parameters for Western blotting

\begin{tabular}{|c|c|c|c|}
\hline Item & $\begin{array}{l}\text { Primary antibody } \\
\text { dilution rate }\end{array}$ & $\begin{array}{l}\text { Second antibody } \\
\text { dilution rate }\end{array}$ & $\begin{array}{l}\text { Duration of } \\
\text { autoradiography } \\
\text { (min) }\end{array}$ \\
\hline CD80 & $\begin{array}{l}\text { 1:100 (goat anti- } \\
\text { human CD } 80 \\
\text { antibody) }\end{array}$ & $\begin{array}{l}\text { 1:2,500 (mouse } \\
\text { anti-goat IG } \\
\text { antibody) }\end{array}$ & 300 \\
\hline CD86 & $\begin{array}{l}\text { 1:100 (goat anti- } \\
\text { human CD86 } \\
\text { antibody) }\end{array}$ & $\begin{array}{l}\text { 1:7,000 (mouse } \\
\text { anti-goat IG } \\
\text { antibody) }\end{array}$ & 300 \\
\hline CD83 & $\begin{array}{l}\text { 1:100 (rabbit anti- } \\
\text { human CD83 } \\
\text { antibody) }\end{array}$ & $\begin{array}{l}\text { 1:8,000 (mouse } \\
\quad \text { anti-rabbit IG } \\
\text { antibody) }\end{array}$ & 300 \\
\hline CD28 & $\begin{array}{l}\text { 1:100 (goat anti- } \\
\text { human CD86 } \\
\text { antibody) }\end{array}$ & $\begin{array}{l}\text { 1:5,000 (mouse } \\
\text { anti-goat IG } \\
\text { antibody) }\end{array}$ & 300 \\
\hline CTLA4 & $\begin{array}{l}\text { 1:100 (goat anti- } \\
\text { human CD86 } \\
\text { antibody) }\end{array}$ & $\begin{array}{l}\text { 1:5,000 (mouse } \\
\text { anti-goat IG } \\
\text { antibody) }\end{array}$ & 360 \\
\hline CD40 & $\begin{array}{l}\text { 1:100 (goat anti- } \\
\text { human CD } 86 \\
\text { antibody) }\end{array}$ & $\begin{array}{l}\text { 1:2,500 (mouse } \\
\text { anti-goat IG } \\
\text { antibody) }\end{array}$ & 300 \\
\hline ICAM-1 & $\begin{array}{l}\text { 1:500 (rabbit anti- } \\
\text { human CD83 } \\
\text { antibody) }\end{array}$ & $\begin{array}{l}\text { 1:5,000 (mouse } \\
\text { anti-rabbit IG } \\
\text { antibody) }\end{array}$ & 60 \\
\hline$\beta$-Actin & $\begin{array}{l}\text { 1:5,000 (mouse anti- } \\
\text { human } \beta \text {-actin } \\
\text { antibody) }\end{array}$ & $\begin{array}{l}\text { 1:15,000 (goat } \\
\text { anti-mouse IG } \\
\text { antibody) }\end{array}$ & 10 \\
\hline
\end{tabular}

Costimulatory protein are present in low concentrations. The duration of autoradiography for each protein was determined at different durations, viz. 10, 20, 40, 60, 120, 180, 240, 300, 360 and $420 \mathrm{~min}$, with the optimal duration being used for each specific protein

B1) and recombinant human CD86 protein (140-B2), were purchased from $R \& D$ Inc. Pre-staining protein marker (P7708S) was obtained from New England BioLabs, (USA), and ABC immunochemical kits from Vector Laboratories Inc. (Burlingame, CA, USA). All other reagents were bought from Sigma.

Western blotting of costimulatory proteins in liver

The relative quantity of costimulatory proteins and of DC marker proteins in liver were detected by Western blotting as described by Zhong et al. [18]. Livers were homogenized in lysis buffer containing $50 \mathrm{~mm}$ Tris $\mathrm{HCl}(\mathrm{pH} \mathrm{6.8)}$, $2 \%$ sodium dodecyl sulfate, $10 \%$ glycerol, $50 \mathrm{~mm}$ dithiothreitol and $0.1 \%$ bromophenol blue, and were diluted to $1 \mathrm{mg}$ total protein/ml. Samples and lysate of liver tissue were resolved in $8 \%$ SDS-PAGE. Proteins were blotted onto nitrocellulose membrane and incubated with primary antibody and secondary antibody. Immune complexes were visualized using an enhanced chemiluminescence substrate by $\mathrm{ECL}^{\mathrm{TM}}$ (Amersham Pharmacia Biotech, Arlington Heights, IL, USA). The duration of autoradiography in 
Table 2 PCR primer sequences and annealing temperature for detecting items

\begin{tabular}{lll}
\hline Cytokine & Sequence & Annealing temperature $\left({ }^{\circ} \mathrm{C}\right)$ \\
\hline IFN- $\gamma$ & F 5'-GGAGACCATCAAGGAAGACAT-3' & 59 \\
& R 5'-GCGACAGTTCAGCCATCAC-3' & \\
IL-6 & F 5'-AAGCCAGAGCTGTGCAGATGAGTA-3' & 64 \\
& R 5'-TGTCCTGCAGCCACTGGTTC-3' & \\
IL-10 & F 5'-GAGATGCCTTCAGCAGAGTGAAGA-3' & 64 \\
& R 5'-AGGCTTGGCAACCCAGGTAAC-3' & \\
IL-18 & F 5'-GCCTGGACAGTCAGCAAGGA-3' & 60.5 \\
& R 5'-TCTACTGGTTCAGCAGCCATCTTTA-3' & \\
$\beta$-actin & F 5'-TATCCTGGCTGTGCTATCCC-3' & 59 \\
& R 5'-CCATCTCTTGCTCGAAGTCC-3' & \\
\hline
\end{tabular}

each protein is shown in Table 1 , and the images on the $\mathrm{X}$-ray membrane were scanned. The relative quantity of protein was normalized to the protein quantity for each sample using $\beta$-actin protein as an internal standard.

Costimulatory proteins are membrane proteins on immune cells, and their content in tissue is very low. Therefore, the common technique of Western blotting is not useful for detecting costimulatory proteins in tissue. In the preliminary experiment for each protein, the liver tissue obtained from a Cir patient was firstly used to determine the optimal antibody dilution rate. The duration of autoradiography for each protein was then determined at different durations, viz. 10, 20, 40, 60, $120,180,240,300,360$ and $420 \mathrm{~min}$, with the optimal duration being used for each specific protein. The optimal parameters are shown in Table 1.

\section{Immunohistochemistry and histology}

Histological sections of liver stained with hematoxylin and eosin (H\&E) azure and with immunohistochemical stains of CD80, CD86, CD83, CD28, CD40, CTLA-4 and ICAM1 were observed by light microscopy. The liver specimens were fixed in $4 \%$ neutral buffered formalin, and embedded in paraffin. Sections $6 \mu \mathrm{m}$ thick were prepared, deparaffined, and rinsed three times with 0.01 M PBS (pH 7.4). The sections were rehydrated and incubated with $1 \%$ trypsinase (Sigma) for $20 \mathrm{~min}$ at $37{ }^{\circ} \mathrm{C}$ in order to retrieve antigen. They were then treated with $0.3 \% \mathrm{H}_{2} \mathrm{O}_{2}$ for $15 \mathrm{~min}$ to eliminate endogenous peroxidase. After blocking with nonspecific staining, the sections were incubated with primary antibody. The secondary antibody coupled to horseradish peroxidase was incubated at room temperature for $30 \mathrm{~min}$, and then processed using the $\mathrm{ABC}$ kit of immunoperoxidase stains. Finally, these sections were counterstained with hematoxylin. The negative controls were performed by omitting the first antibody.

The necroinflammatory lesions and fibrosis were graded by the Ishak modified HAI system [19]. The maximum possible score in this system for grading of necroinflammation was 18 , and for fibrosis was 6 . The distribution of costimulatory proteins in liver was revealed by immunohistochemical staining.

Real-time quantitative PCR of cytokine mRNA in liver

Real-time quantitative PCR and data analysis were performed as described by Zhong et al. [18]. Total RNA in the liver was extracted using an RNeasy mini kit (Generay Biotech Co., Shanghai, China). One $\mu$ g of total RNA was reverse transcribed in a $20 \mu$ volume using an RT-PCR kit (Promega Corporation, USA) according to the manufacturer's instruction.

The primer sets were predesigned by Applied Biosystems. The primer sequences and annealing temperatures are shown in Table 2; and the 45-cycle PCR was performed for all items. The cytokine mRNA was normalized to RNA loading for each sample using $\beta$-actin mRNA as an internal standard. The relative mRNA quantity, including interferon (IFN)- $\gamma$, interleukin (IL)-6, IL-18 and IL-10 were detected using Engine Option $^{\mathrm{TM}}$ (MJReseach, USA) by SYBR Green I.

Statistical analysis

Data are given as means (minimal-maximal). Clinical and immunological parameters were compared by the KruskalWallis test, Nemenyi test and $M$ test (Friedman). Correlations between ALT, necroinflammatory scores, cytokine mRNA and costimulatory proteins were assessed using Spearman's rank correlation coefficient. $p$ values $<0.05$ were considered significant.

\section{Results}

No evidence of hepatitis in ACs, but various characteristics of liver disease in $\mathrm{ACH}$, Cir and HCC patients

The patients' characteristics are shown in Table 3. The ACs presented high viral loads with positive $\mathrm{HBeAg}$ but 
Table 3 Patient characteristics

\begin{tabular}{|c|c|c|c|c|c|c|c|c|c|c|c|}
\hline Groups & $\begin{array}{l}\text { Age } \\
(\text { years)/ } \\
\text { sex }\end{array}$ & Diagnosis & $\begin{array}{l}\text { HbsAg: } \\
0-1.0 \\
\text { S/CO }\end{array}$ & $\begin{array}{l}\text { HbeAg: } \\
0-0.28 \\
\text { PEIU/ml }\end{array}$ & $\begin{array}{l}\mathrm{HBcAb}: \\
1-3 \\
\mathrm{~S} / \mathrm{CO}\end{array}$ & $\begin{array}{l}\text { HBV-DNA: } \\
<2.70 \\
\text { copies/ml } \\
(\log )\end{array}$ & $\begin{array}{l}\text { TB: } 5.1- \\
19 \mu \mathrm{mol} / \\
\mathrm{L}\end{array}$ & $\begin{array}{l}\text { DB: } 1.7- \\
6.8 \mu \mathrm{mol} / \\
\mathrm{L}\end{array}$ & $\begin{array}{l}\text { ALT: } \\
5-40 \\
\mathrm{u} / \mathrm{L}\end{array}$ & $\begin{array}{l}\text { Histology: } \\
\text { necroinflammation score } \\
\text { (N 0-18) and fibrosis } \\
\text { score (F 0-6) }\end{array}$ & $\begin{array}{l}\text { Liver } \\
\text { specimen } \\
\text { obtained } \\
\text { from: }\end{array}$ \\
\hline HD 1 & $55 / \mathrm{M}$ & $\begin{array}{l}\text { Donor liver } \\
\text { from liver } \\
\text { transplant } \\
\text { operation }\end{array}$ & Neg & $\mathrm{Neg}$ & Neg & $<2.70$ & $\begin{array}{l}\text { Normal } \\
\text { (Nor) }\end{array}$ & Nor & Nor & $\mathrm{N} 1$ and $\mathrm{F} 0$ & Surgical \\
\hline HD 2 & $47 / \mathrm{M}$ & $\begin{array}{l}\text { Donor liver } \\
\text { from liver } \\
\text { transplant } \\
\text { operation }\end{array}$ & Neg & $\mathrm{Neg}$ & Neg & $<2.70$ & Nor & Nor & Nor & $\mathrm{N} 1$ and $\mathrm{F} 0$ & Surgical \\
\hline HD 3 & 39/M & $\begin{array}{l}\text { Donor liver } \\
\text { from liver } \\
\text { transplant } \\
\text { operation }\end{array}$ & Neg & Neg & Neg & $<2.70$ & Nor & Nor & Nor & $\mathrm{N} 0$ and $\mathrm{F} 0$ & Surgical \\
\hline HD 4 & $27 / F$ & $\begin{array}{l}\text { Donor liver } \\
\text { from liver } \\
\text { transplant } \\
\text { operation }\end{array}$ & Neg & Neg & Neg & $<2.70$ & Nor & Nor & Nor & $\mathrm{N} 0$ and $\mathrm{F} 0$ & Surgical \\
\hline HD 5 & $35 / \mathrm{M}$ & $\begin{array}{l}\text { Donor liver } \\
\text { from liver } \\
\text { transplant } \\
\text { operation }\end{array}$ & Neg & Neg & Neg & $<2.70$ & Nor & Nor & Nor & $\mathrm{N} 1$ and $\mathrm{F} 0$ & Surgical \\
\hline HD 6 & $32 / \mathrm{M}$ & $\begin{array}{l}\text { Donor liver } \\
\text { from spleen } \\
\text { trauma } \\
\text { operation }\end{array}$ & Neg & Neg & $\mathrm{Neg}$ & $<2.70$ & Nor & Nor & Nor & $\mathrm{N} 0$ and $\mathrm{F} 0$ & Surgical \\
\hline $\mathrm{AC} 1$ & $51 / \mathrm{F}$ & $\begin{array}{c}\text { Gastric ulcer } \\
\text { operation }\end{array}$ & 102.67 & 13.318 & 0.067 & 5.43 & 19.0 & 7.3 & 35.7 & $\mathrm{~N} 1$ and $\mathrm{F} 1$ & Surgical \\
\hline $\mathrm{AC} 2$ & $33 / \mathrm{M}$ & $\begin{array}{l}\text { Gastric } \\
\text { perforation } \\
\text { operation }\end{array}$ & 136.73 & 384.072 & 0.104 & 8.08 & 15.7 & 6.8 & 28.5 & $\mathrm{~N} 0$ and $\mathrm{F} 0$ & Surgical \\
\hline AC 3 & 38/M & $\begin{array}{c}\text { Spleen trauma } \\
\text { operation }\end{array}$ & 79.42 & 459.150 & 0.166 & 6.91 & 20.1 & 5.3 & 39.8 & $\mathrm{~N} 1$ and $\mathrm{F} 0$ & Surgical \\
\hline $\mathrm{AC} 4$ & $24 / \mathrm{M}$ & $\begin{array}{c}\text { Duodenal ulcer } \\
\text { perforation } \\
\text { operation }\end{array}$ & 288.15 & $4,285.613$ & 0.064 & 9.15 & 17.9 & 7.2 & 37.1 & $\mathrm{~N} 1$ and $\mathrm{F} 0$ & Surgical \\
\hline $\mathrm{AC} 5$ & $18 / \mathrm{M}$ & HBV carrier & 186.76 & $1,187.912$ & 0.078 & 9.45 & 18.7 & 3.2 & 30.9 & Undetection & Biopsy \\
\hline $\mathrm{AC} 6$ & $36 / \mathrm{M}$ & HBV carrier & 213.07 & $2,237.512$ & 0.051 & 8.54 & 21.1 & 7.6 & 32.6 & Undetection & Biopsy \\
\hline $\mathrm{AC} 7$ & $22 / \mathrm{M}$ & HBV carrier & 138.72 & 18.534 & 0.173 & 6.86 & 22.6 & 6.4 & 38.7 & Undetection & Biopsy \\
\hline $\mathrm{AC} 8$ & $26 / \mathrm{M}$ & HBV carrier & 144.39 & 88.969 & 0.249 & 7.81 & 9.1 & 3.1 & 20.8 & Undetection & Biopsy \\
\hline $\mathrm{AC} 9$ & $23 / \mathrm{M}$ & HBV carrier & 119.46 & $1,084.750$ & 0.094 & 8.88 & 8.7 & 4.2 & 22.0 & $\mathrm{~N} 0$ and $\mathrm{F} 0$ & Biopsy \\
\hline AC 10 & $28 / \mathrm{M}$ & HBV carrier & 478.03 & $2,371.143$ & 0.238 & 8.80 & 17.4 & 6.1 & 32.1 & $\mathrm{~N} 1$ and $\mathrm{F} 0$ & Biopsy \\
\hline $\mathrm{ACH} 1$ & $50 / \mathrm{M}$ & $\begin{array}{l}\mathrm{ACH} \text {, hepatic } \\
\text { failure } \\
\text { transplant }\end{array}$ & 6.12 & 396.641 & 0.065 & 5.34 & 261.3 & 114.7 & 120.8 & $\mathrm{~N} 18$ and $\mathrm{F} 2$ & Liver \\
\hline $\mathrm{ACH} 2$ & $46 / \mathrm{M}$ & $\begin{array}{l}\mathrm{ACH} \text {, hepatic } \\
\text { failure } \\
\text { transplant }\end{array}$ & 3.41 & 2.693 & 0.196 & 2.90 & 128.3 & 60.4 & $4,039.0$ & $\mathrm{~N} 18$ and $\mathrm{F} 2$ & Liver \\
\hline $\mathrm{ACH} 3$ & 38/M & $\mathrm{ACH}$ & 291.28 & 48.509 & 0.086 & 4.15 & 71.1 & 25.8 & 917.0 & Undetection & Biopsy \\
\hline $\mathrm{ACH} 4$ & $22 / \mathrm{M}$ & $\mathrm{ACH}$ & 98.12 & 33.375 & 0.079 & 4.46 & 19.4 & 5.1 & 558.6 & Undetection & Biopsy \\
\hline $\mathrm{ACH} 5$ & $22 / \mathrm{M}$ & $\mathrm{ACH}$ & 159.12 & 4.265 & 0.132 & 7.61 & 29.9 & 14.8 & 184.5 & Undetection & Biopsy \\
\hline ACH 6 & $26 / \mathrm{M}$ & $\mathrm{ACH}$ & 148.31 & 42.274 & 0.095 & 7.08 & 20.9 & 8.6 & 323.8 & Undetection & Biopsy \\
\hline $\mathrm{ACH} 7$ & $21 / \mathrm{M}$ & $\mathrm{ACH}$ & 119.18 & 731.640 & 0.067 & 6.62 & 9.1 & 2.2 & 474.1 & Undetection & Biopsy \\
\hline $\mathrm{ACH} 8$ & 33/M & $\mathrm{ACH}$ & 98.14 & $1,347.302$ & 0.059 & 8.56 & 17.9 & 2.8 & 130.5 & Undetection & Biopsy \\
\hline
\end{tabular}


Table 3 continued

\begin{tabular}{|c|c|c|c|c|c|c|c|c|c|c|c|}
\hline Groups & $\begin{array}{l}\text { Age } \\
\text { (years)/ } \\
\text { sex }\end{array}$ & Diagnosis & $\begin{array}{l}\text { HbsAg: } \\
0-1.0 \\
\text { S/CO }\end{array}$ & $\begin{array}{l}\text { HbeAg: } \\
0-0.28 \\
\text { PEIU/ml }\end{array}$ & $\begin{array}{l}\mathrm{HBcAb}: \\
1-3 \\
\mathrm{~S} / \mathrm{CO}\end{array}$ & $\begin{array}{l}\text { HBV-DNA: } \\
<2.70 \\
\text { copies/ml } \\
(\log )\end{array}$ & $\begin{array}{l}\text { TB: } 5.1- \\
19 \mu \mathrm{mol} / \\
\mathrm{L}\end{array}$ & $\begin{array}{l}\text { DB: } 1.7- \\
6.8 \mu \mathrm{mol} / \\
\mathrm{L}\end{array}$ & $\begin{array}{l}\text { ALT: } \\
5-40 \\
\text { u/L }\end{array}$ & $\begin{array}{l}\text { Histology: } \\
\text { necroinflammation score } \\
\text { (N 0-18) and fibrosis } \\
\text { score (F 0-6) }\end{array}$ & $\begin{array}{l}\text { Liver } \\
\text { specimen } \\
\text { obtained } \\
\text { from: }\end{array}$ \\
\hline $\mathrm{ACH} 9$ & $32 / \mathrm{M}$ & $\mathrm{ACH}$ & 105.25 & 564.652 & 0.112 & 8.04 & 12.7 & 3.8 & 151.7 & Undetection & Biopsy \\
\hline ACH 10 & $27 / \mathrm{M}$ & $\mathrm{ACH}$ & 223.97 & $1,758.515$ & 0.264 & 9.20 & 19.6 & 8.8 & 532.0 & Undetection & Biopsy \\
\hline ACH 11 & $28 / \mathrm{M}$ & $\mathrm{ACH}$ & 231.85 & 7.720 & 0.102 & 2.91 & 23.2 & 11.4 & 140.8 & $\mathrm{~N} 12$ and $\mathrm{F} 1$ & Biopsy \\
\hline $\mathrm{ACH} 12$ & $40 / \mathrm{M}$ & $\mathrm{ACH}$ & 69.05 & 152.573 & 0.050 & 4.11 & 173.2 & 55.9 & 252.5 & $\mathrm{~N} 17$ and $\mathrm{F} 1$ & Biopsy \\
\hline ACH 13 & $20 / \mathrm{M}$ & $\mathrm{ACH}$ & 59.90 & 0.800 & 0.068 & 5.92 & 35.5 & 11.8 & 109.1 & $\mathrm{~N} 12$ and $\mathrm{F} 1$ & Biopsy \\
\hline ACH 14 & $39 / \mathrm{M}$ & $\mathrm{ACH}$ & 80.51 & 560.840 & 0.052 & 8.81 & 25.3 & 11.3 & 96.0 & $\mathrm{~N} 12$ and $\mathrm{F} 2$ & Biopsy \\
\hline Cir 1 & $36 / \mathrm{M}$ & $\begin{array}{l}\text { Cirrhosis } \\
\text { operation }\end{array}$ & 153.33 & 2.775 & 0.084 & 6.78 & 40.6 & 8.0 & 43.0 & N 8 and F 6 & Surgical \\
\hline Cir 2 & $38 / \mathrm{M}$ & $\begin{array}{l}\text { Cirrhosis } \\
\text { transplant }\end{array}$ & 70.12 & 8.59 & 0.183 & 4.84 & 41 & 16.7 & 66.5 & N 8 and F 6 & Liver \\
\hline Cir 3 & $28 / \mathrm{M}$ & $\begin{array}{l}\text { Cirrhosis } \\
\text { transplant }\end{array}$ & 70.96 & 417.763 & 0.108 & 6.18 & 57 & 23.7 & 96.8 & N 8 and F 6 & Liver \\
\hline Cir 4 & $49 / \mathrm{M}$ & $\begin{array}{l}\text { Cirrhosis } \\
\text { operation }\end{array}$ & 118.96 & 7.159 & 0.063 & 4.30 & 57.7 & 25.9 & 212.6 & N 9 and F 6 & Surgical \\
\hline Cir 5 & $56 / \mathrm{M}$ & $\begin{array}{l}\text { Cirrhosis } \\
\text { transplant }\end{array}$ & 31.87 & 15.504 & 0.071 & 3.85 & 117.7 & 56.2 & 39.0 & N 8 and $\mathrm{F} 6$ & Liver \\
\hline Cir 6 & $43 / M$ & $\begin{array}{l}\text { Cirrhosis } \\
\text { operation }\end{array}$ & 145.73 & 9.49 & 0.064 & 6.11 & 27.8 & 15.6 & 60.0 & N 5 and F 6 & Surgical \\
\hline HCC 1 & $67 / \mathrm{M}$ & $\begin{array}{l}\text { Hepatocellular } \\
\text { carcinoma } \\
\text { operation }\end{array}$ & 29.87 & 5.504 & 0.038 & 4.53 & 16.7 & 6.8 & 67.4 & $\mathrm{~N} 5$ and $\mathrm{F} 2$ & Surgical \\
\hline HCC 2 & $46 / \mathrm{M}$ & $\begin{array}{l}\text { Hepatocellular } \\
\text { carcinoma } \\
\text { operation }\end{array}$ & 82.84 & 11.203 & 0.115 & 6.20 & 30.1 & 10.0 & 28.3 & $\mathrm{~N} 3$ and $\mathrm{F} 1$ & Surgical \\
\hline HCC 3 & $37 / \mathrm{M}$ & $\begin{array}{l}\text { Hepatocellular } \\
\text { carcinoma } \\
\text { operation }\end{array}$ & 147.56 & 48.483 & 0.094 & 7.84 & 18.6 & 7.5 & 89.0 & $\mathrm{~N} 5$ and $\mathrm{F} 0$ & Surgical \\
\hline $\mathrm{HCC} 4$ & $53 / \mathrm{M}$ & $\begin{array}{l}\text { Hepatocellular } \\
\text { carcinoma } \\
\text { operation }\end{array}$ & 51.34 & 1.147 & 0.152 & 5.88 & 10.0 & 4.6 & 63.0 & $\mathrm{~N} 3$ and $\mathrm{F} 1$ & Surgical \\
\hline HCC 5 & $56 / \mathrm{M}$ & $\begin{array}{l}\text { Hepatocellular } \\
\text { carcinoma } \\
\text { operation }\end{array}$ & 178.68 & 1.31 & 0.052 & 4.04 & 24.5 & 8.4 & 18.0 & $\mathrm{~N} 2$ and $\mathrm{F} 2$ & Surgical \\
\hline HCC 6 & $38 / \mathrm{F}$ & $\begin{array}{l}\text { Hepatocellular } \\
\text { carcinoma } \\
\text { operation }\end{array}$ & 181.75 & 4.312 & 0.043 & 6.34 & 6.7 & 4.5 & 69.0 & N 3 and F 1 & Surgical \\
\hline
\end{tabular}

Protein quantity was estimated by Western blotting in the biopsy subjects AC 5-6 and ACH 3-6, mRNA quantity was detected by real-time quantitative PCR in AC7-8 and ACH 7-10, immunohistochemistry staining was performed in AC 9-10 and ACH 11-14. All three detections, protein quantity, mRNA quantity and immunohistochemistry staining, were performed in the surgical specimens of HD 1-6, AC 1-4, ACH 1-2, Cir 1-6 and HCC 1-6. The necroinflammatory lesions and fibrosis were graded according to the Ishak modified HAI. The maximum possible scores for necroinflammation and fibrosis were 18 and 6 , respectively

normal ALT, whereas ACH patients exhibited increased ALT. Cir and HCC patients showed abnormal or normal ALT. By histological observation, ACs exhibited no evidence of hepatitis in liver or spotty lytic necrosis and apoptosis in lobules (necroinflammatory and fibrosis scores $\mathrm{N} 0-1$ and $\mathrm{F}$ 0-1, respectively), similar to $\mathrm{HDs}$; $\mathrm{ACH}$ patients showed severe necroinflammation and slight fibrosis (N 12-18 and F 1-2); and Cir patients presented mild necroinflammation and definite fibrosis (N 5-9 and F 6). However, HCC patients displayed slight necroinflammation and fibrosis in non-tumor tissue, namely focal lytic necrosis, focal inflammation, piecemeal necrosis or slight fibrosis (N 2-5 and F 0-2). The data in Table 3 show that there was no evidence of hepatitis in ACs but various characteristics of liver disease in $\mathrm{ACH}$, $\mathrm{Cir}$ and $\mathrm{HCC}$ patients. 

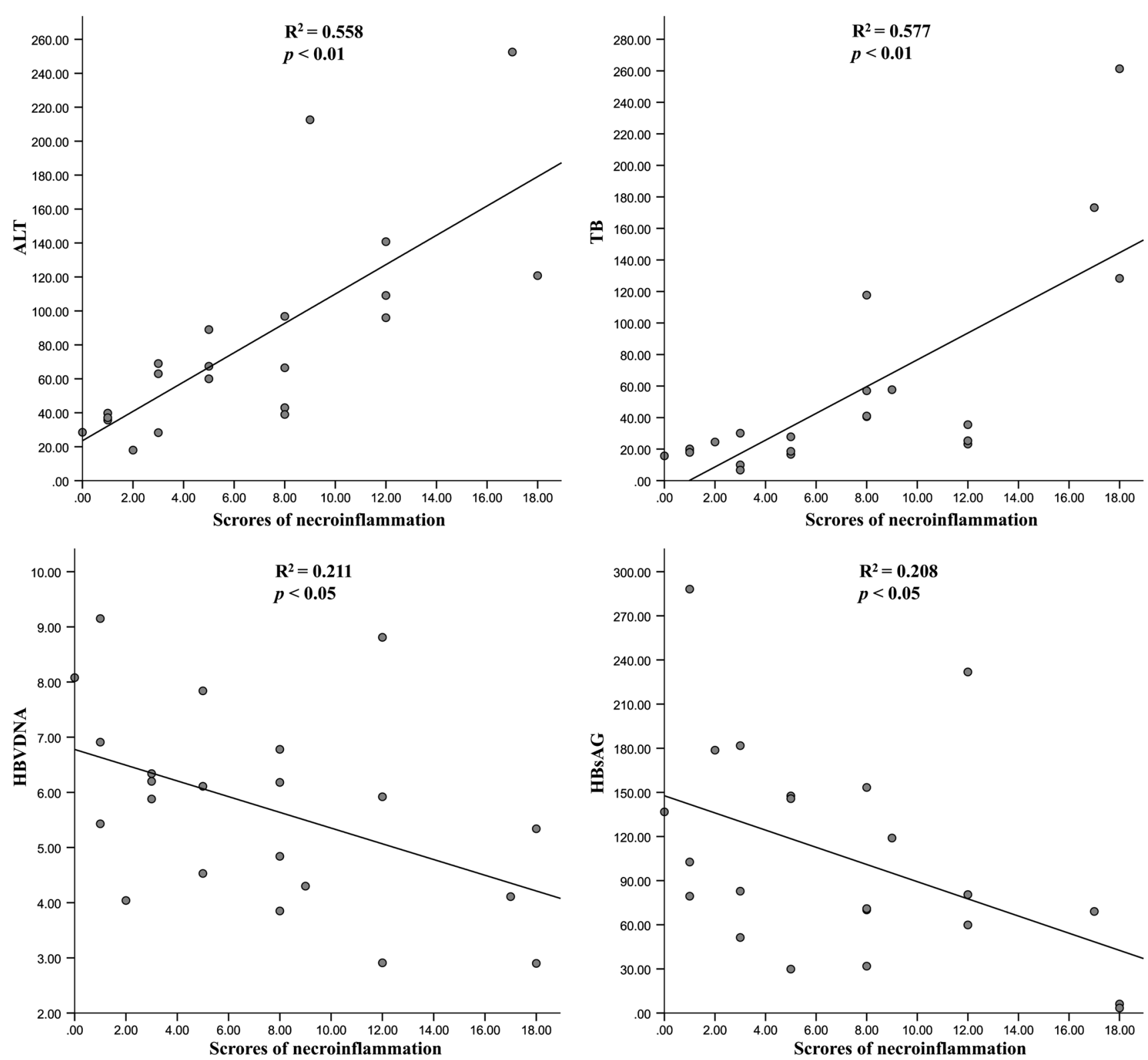

Fig. 1 Correlation between intrahepatic scores of necroinflammation and serum ALT, TB, HBsAg or HBV-DNA load. The histological examination of liver tissues was performed in 24 CHB patients, 6 patients in each group. The intrahepatic scores of necroinflammation were graded by the system of Ishak modified HAI. The correlation

coefficient between the scores of necroinflammation and ALT, TB, HBsAg or HBV-DNA load was analyzed. The scores of necroinflammation in liver were positively correlated with ALT and TB, but negatively correlated with HBsAg and HBVDNA load in all the CHB patients

On correlation analysis, necroinflammatory scores in liver were positively correlated with ALT and total bilirubin (TB), but negatively correlated with HBsAg and HBV-DNA load in all CHB patients (Fig. 1). The results shown in Fig. 1 suggest that increased ALT and TB in peripheral blood and the severity of necroinflammation in liver were closely interconnected, and that high inflammatory responses partially inhibited HBV replication.

Identification of CD80 and CD86 proteins in liver

Costimulation signals are regulated by costimulatory proteins instead of their mRNA. However, human intrahepatic costimulatory proteins have not previously been detected quantitatively [4-9, 20]. In this study, we tried to identify costimulatory proteins in liver. CD80 and CD86 proteins were identified using the method described in Fig. 2a. The molecular weight of CD86 protein in human liver was $80 \mathrm{kDa}$, and that of 
A

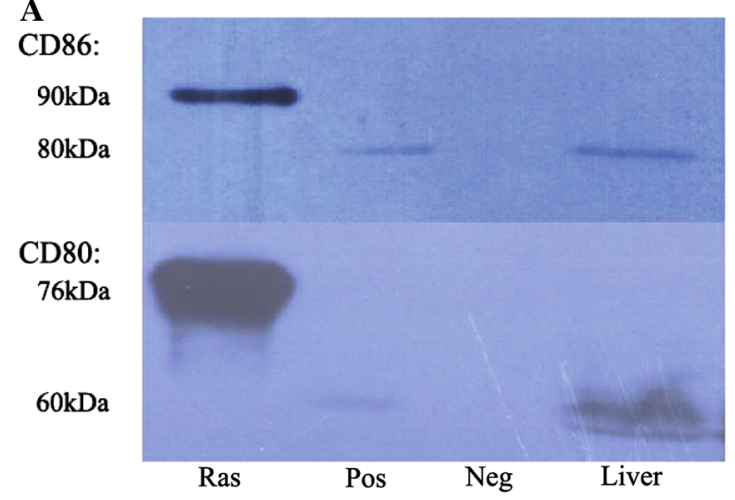

B

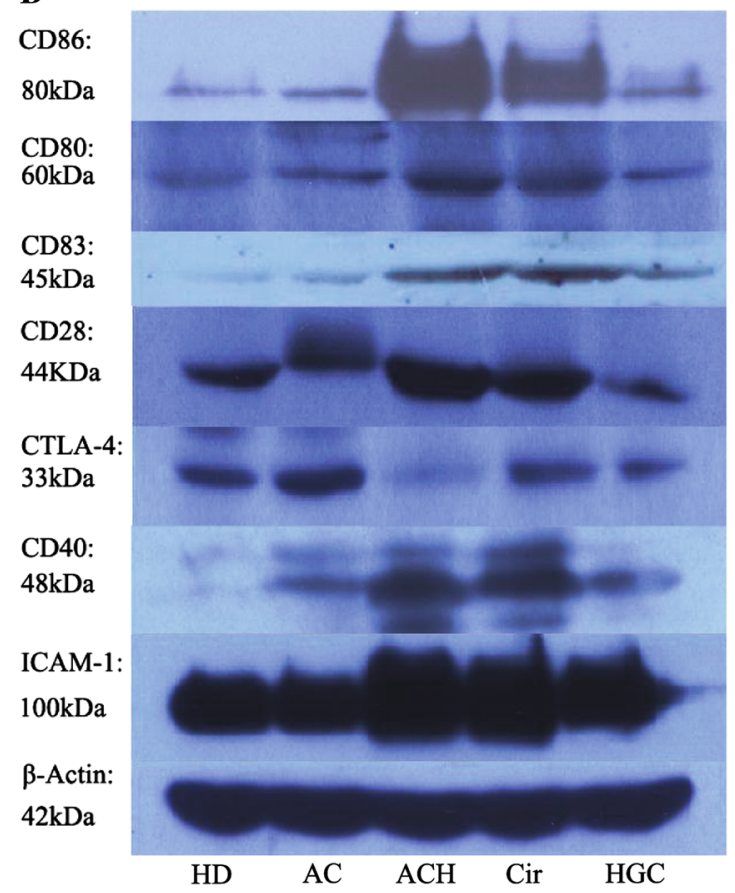

C
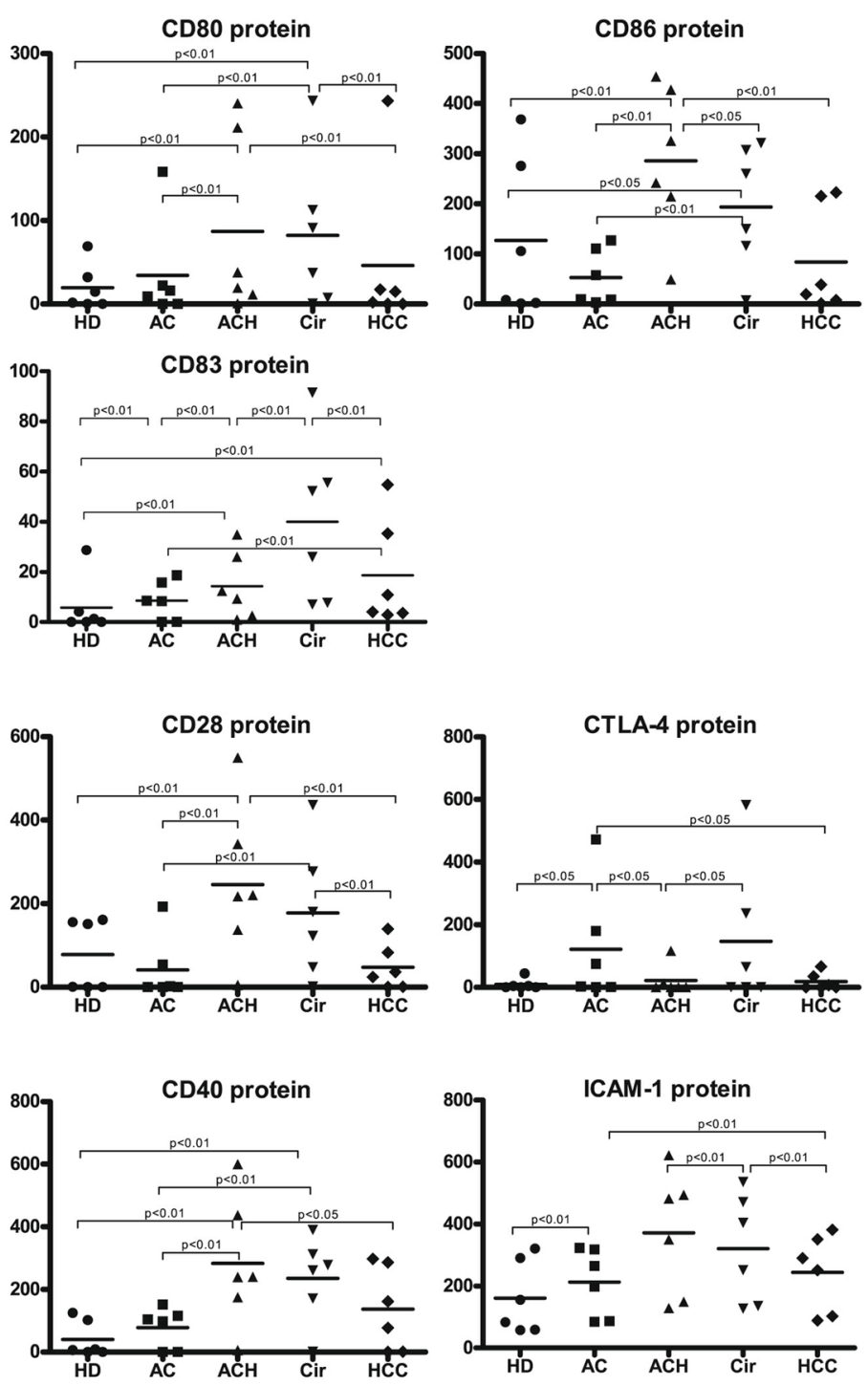

IL-18-mRNA
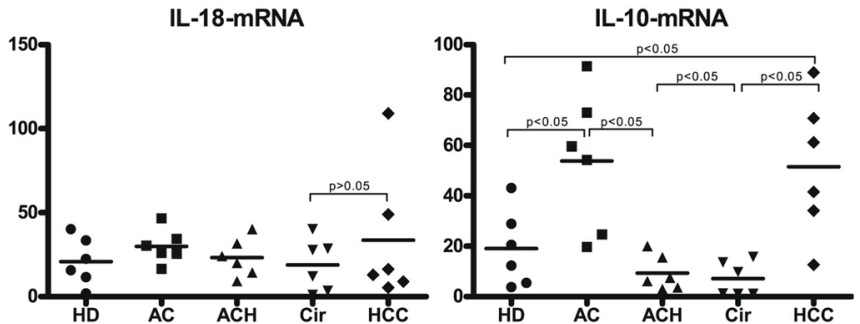

CD80 protein was $60 \mathrm{kDa}$. In this study, we were the first to identify costimulatory proteins in human liver tissue.

Increased markers of DC maturation in $\mathrm{ACH}$ and Cir patients

The surface of DCs presents CD80, CD86 and CD83. Matured DCs show signs of increased CD80, CD86 and CD83, resulting in activation of T cells and contributing to immune responses in the liver $[7,11]$. Therefore, we analyzed the expression of CD80, CD86 and CD83 and observed the localization of $\mathrm{CD}^{+} 0^{+}, \mathrm{CD}^{+} 6^{+}$and $\mathrm{CD} 83^{+}$ cells in liver in order to explore the functional state of DCs. First, we quantitatively detected the levels of CD80, CD86 and CD83 in liver by Western blotting. Figure 2b, c show that $\mathrm{CD} 80$ protein levels in $\mathrm{ACH}$ and $\mathrm{Cir}$ patients were higher than those in ACs, HDs or HCC patients $(p<0.05)$, that $\mathrm{CD} 86$ protein levels in $\mathrm{ACH}$ patients were higher than 
4Fig. 2 Quantitative detection of costimulatory proteins or cytokine mRNA in liver. a Identification of CD80 and CD86 in liver. Western blotting was performed using a specific antibody against human costimulatory protein. Recombinant human CD80 and CD86 proteins, positive control CD80 protein (separate Ramos cell) and CD86 protein (separate Jurkat cell), negative control and liver homogenates of human were applied to determination of CD80 and CD86 in liver tissue. In the same western blotting, recombinant protein (Rec), positive control (Pos), negative control (Neg) and liver homogenates of human (Liver) were subjected to electrophoresis. In the photograph of CD86 protein, the molecular weight of recombinant CD86 protein was $90 \mathrm{kDa}$, and that of CD86 protein in human liver was $80 \mathrm{kDa}$. In the photograph of CD80, the molecular weight of recombinant CD80 protein was $76 \mathrm{kDa}$, and that of CD80 protein in human liver was $60 \mathrm{kDa}$. b Representative western blotting of costimulatory proteins in livers from six separate experiments. Homogenates obtained from the livers in the five groups were subjected to electrophoresis. $\beta$-Actin protein served as a protein loading standard. The molecular weight of CD86, CD80, CD83, CD28, CTLA-4, CD40, ICAM-1 and $\beta$-actin was $80,60,45,44,33,48,100$ and $42 \mathrm{kDa}$, respectively. The CD80 stains in the $\mathrm{ACH}$ or Cir patient were darker than those in the $\mathrm{HD}, \mathrm{AC}$ or HCC subject. The CD86 stains showed that the stains in the ACH or Cir patient were also darker than those in the HD, AC or HCC subject. In CD83 stains, the photograph showed dark stains of CD83 in the Cir patient. The photograph showed dark stains of CD28 and weak stains of CTLA-4 in the ACH patient. The stains of CTLA-4 in the $\mathrm{AC}$ or Cir patient were darker than those in the ACH, HD or HCC patient, whereas the stains in the $\mathrm{ACH}$ patient were weaker than those in other subjects. As the CD40 photograph showed, the dark stains of CD40 presented in the ACH or Cir patient. The ICAM-1 stains showed that the stains in the $\mathrm{ACH}$ and Cir patients were darker than those in the HD, AC and HCC subjects. c Relative quantity of costimulatory proteins in livers of the five groups $(n=6$, in each group). The images on X-ray membrane were scanned, and the relative quantity of protein was normalized to the protein quantity for each sample using $\beta$-actin protein. All the parameters were shown in this figure. The data showed increased CD80, CD86, CD83, CD28 and CD40 and decreased CTLA-4 in the $\mathrm{ACH}$ patient, increased CD80, CD86, CD83, CD28, CD40 and CTLA-4 in the Cir patient, increased CTLA-4 and decreased CD80, CD86, CD28 and CD40 in the AC subject, and decreased CD80, CD86, CD28, CD40 and CTLA-4 in the HCC patient. The ICAM-1 levels in the five groups were gradually declined in the order of the $\mathrm{ACH}$ group, the Cir group, the HCC group, the AC group and the HD group. d Quantitative detection of cytokines mRNA in liver. The relative quantity of the INF $\gamma$ mRNA, IL-6 mRNA, IL-18 mRNA and IL-10 mRNA in liver in all the five groups was detected by real-time quantitative PCR. The data showed unchanged INF $\gamma$ mRNA, IL-6 mRNA and IL18 mRNA in all the five groups, and increased IL-10 mRNA in the AC or HCC patient

those in ACs, HDs, or HCC or Cir patients, that CD86 protein levels in Cir patients were higher than those in HDs or ACs $(p<0.05)$, that CD83 protein levels in Cir patients were higher than those in HDs, ACs, or ACH or HCC patients $(p<0.05)$, and that $\mathrm{CD} 83$ protein levels in $\mathrm{ACH}$ or HCC patients were also higher than those in HDs or ACs $(p<0.05)$. The distribution of CD80, CD83 and CD86 proteins in liver was subsequently explored by immunohistochemistry. $\mathrm{CD} 80^{+}, \mathrm{CD} 83^{+}$or $\mathrm{CD} 86^{+}$cells appeared in the inflammatory zone in the liver tissue of $\mathrm{ACH}$ (Fig. 3a-c) or Cir patients, but few positive cells were identified in ACs, HDs or HCC patients. ACH or Cir patients displayed increased CD80, CD83 and CD86. These results implied that matured $\mathrm{CD} 80^{+}, \mathrm{CD} 83^{+}$and $\mathrm{CD}^{2} 6^{+}$DCs participated in inflammatory responses in the $\mathrm{ACH}$ or Cir patients.

$\mathrm{CD} 28^{+}$cells participate in necroinflammation in $\mathrm{ACH}$ or Cir patients, and increased CTLA- 4 contributes to immune tolerance in $\mathrm{ACs}$

CD28 and CTLA-4, acting as downstream molecules of CD80 and CD86, are attached to the surface of T cells. The CD80, CD86/CD28 pathway provides critical costimulatory signals for naive $\mathrm{T}$ cells. Conversely, the CD80, CD86/CTLA-4 pathway acts as a key negative regulator of CD28-dependent $T$ cells [21]. To evaluate the role of costimulation on $\mathrm{T}$ cells, we quantitatively detected CD28 and CTLA-4 in liver. As shown in Fig. 2b, c, CD28 in $\mathrm{ACH}$ patients was significantly higher than in ACs, HDs or HCC patients $(p<0.05)$, and CD28 in Cir patients was higher than in ACs or HCC patients $(p<0.05)$. CTLA-4 in ACs was higher than in HDs or ACH or HCC patients $(p<0.05)$ and CTLA-4 in Cir patients was higher than in ACH patients $(p<0.05$; Fig. 2b, c). As shown in Fig. 3d, $\mathrm{e}, \mathrm{CD} 28^{+}$cells were localized in the inflammatory zone, but low levels of CTLA-4 staining were found in the inflammatory zone in $\mathrm{ACH}$ patienst. $\mathrm{CD} 28^{+}$cells and CTLA-4 staining were both markedly displayed in Cir patients. These data showed that CD28 increased and CTLA-4 decreased in ACH patients, that CD28 decreased and CTLA- 4 increased in ACs, and that both CD28 and CTLA-4 increased in Cir patients. The above results suggest that $\mathrm{CD} 28^{+}$cells participate in inflammation in $\mathrm{ACH}$ and Cir patients, and that increased CTLA- 4 contributed to immune tolerance in ACs.

\section{CD $40^{+}$cells and ICAM- 1 both participate}

in necroinflammation in $\mathrm{ACH}$ and $\mathrm{Cir}$ patients

Functional $\mathrm{T}$ cells induce activation of $\mathrm{B}$ cells and other immune cells, and cause secretion of inflammatory cytokines. CD40 is expressed on the surface of immune cells or non-immune cells such as B cells, monocytes, endothelial cells, epithelial cells, mesenchymal cells, platelets and malignant tumor cells. Therefore, increased CD40 implies that various immune responses occur in liver disease [22]. ICAM-1 participates in adhesion between various immune cells. Furthermore, both CD40 and ICAM- 1 contribute to the inflammatory reaction and fibrosis generation in progressive liver disease [23]. Therefore, we quantitatively detected the levels of CD40 and ICAM-1. Fig. 2b, c shows that CD40 protein levels in $\mathrm{ACH}$ patients were higher than in HDs or ACs or HCC patients $(p<0.05)$, and CD40 in Cir patients was higher than in HDs or ACs $(p<0.05)$. 


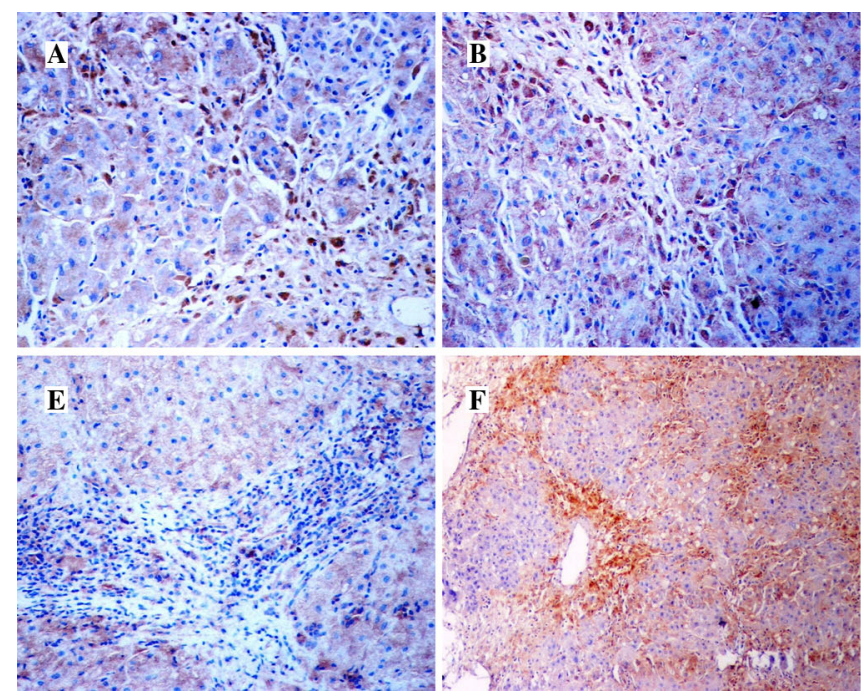

Fig. 3 Distribution of intrahepatic costimulatory proteins by immunochemical staining. Immunohistochemical staining was performed using a specific antibody against human costimulatory protein. In this figure, seven costimulation stains in liver of the ACH patient were shown. a Distribution of CD80 protein in liver. The hepatocytes were surrounded by $\mathrm{CD} 80^{+}$cells and inflammatory cells, $\times 400$ magnification. b Distribution of CD86. CD86 ${ }^{+}$cells were localized in the inflammatory zone and they surrounded the hepatocytes, $\times 400$ magnification. c Distribution of CD83 protein by immunochemical stains. CD83 stains mainly appeared in the inflammatory cells, and

Figure $2 \mathrm{c}$ shows a gradual decrease of ICAM-1 in the five groups in following order: $\mathrm{ACH}$, Cir and $\mathrm{HCC}$ patients, ACs and HDs. Increased CD40 and ICAM-1 were present in $\mathrm{ACH}$ and Cir patients. As shown in Fig. 3f, g, CD40 staining and $\mathrm{CD} 40^{+}$cells were enriched in the necroinflammatory zone, and ICAM- 1 protein was found in the hepatic sinus. CD40 and ICAM-1 were strongly observed in the liver tissue of $\mathrm{ACH}$ and Cir patient. These results implied that $\mathrm{CD}_{4} 0^{+}$cells and ICAM- 1 both contributed to necroinflammation in $\mathrm{ACH}$ and Cir patients.

Increased IL-10 mRNA in liver of AC and HCC patients

Cytokines are divided into inflammatory cytokines and inhibitory cytokines. INF $\gamma$, IL-6 and IL-18 participate in acute inflammatory responses in liver. More importantly, IL 18 expression is mainly located in the liver. Conversely, IL-10 is an inhibitory cytokine and generally contributes to immune suppression. Soluble cytokines are expressed by immune cells and immediately released into the blood. The concentration of cytokine proteins in liver is unstable, but cytokine mRNA in tissue is stable because cytokine mRNA is not released into the blood [18]. We therefore sought cytokine mRNA in liver. Figure $2 \mathrm{e}$ shows that there were no differences in INF- $\gamma$ mRNA, IL-6 mRNA and IL-18
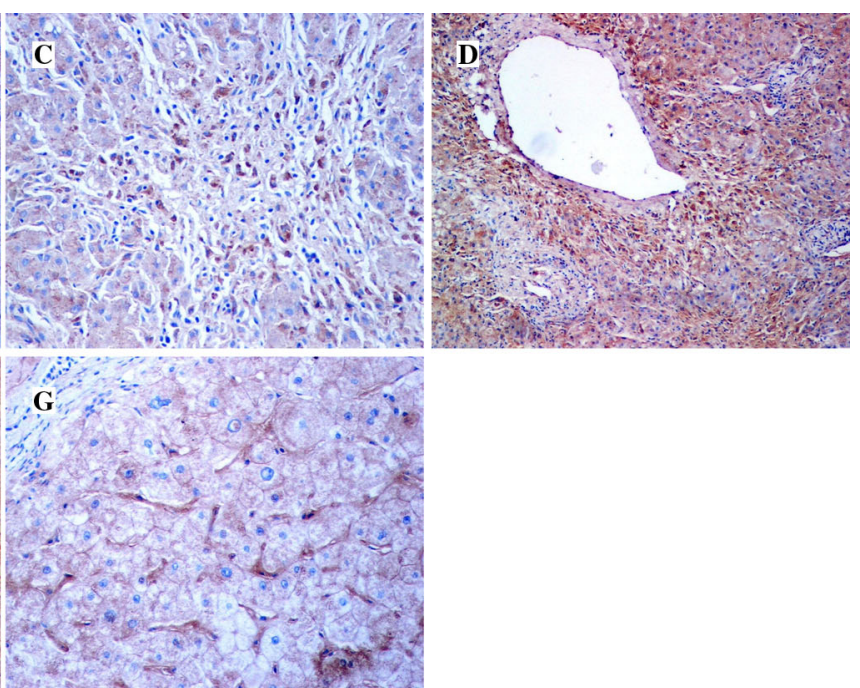

the $\mathrm{CD}_{83}{ }^{+}$cells were localized in the inflammatory-necrotic zone, $\times 400$ magnification. d Distribution of CD28 protein in the liver. $\mathrm{CD} 28^{+}$cells were enriched in the inflammatory zone, $\times 100$ magnification. e CTLA-4 distribution in liver. Few CTLA-4 stains were found in the inflammatory zone in the liver of the $\mathrm{ACH}$ patient, $\times 400$ magnification. $f$ Distribution CD40 in the liver. CD40 ${ }^{+}$cells were enriched in the necrotic zone, and CD40 stains surrounded the hepatocytes, $\times 100$ magnification. g ICAM-1 distribution in liver. Most ICAM-1 stains appeared in the hepatic sinus, $\times 400$ magnification

mRNA between any of the five groups $(p>0.05)$. However, IL-10 mRNA levels in ACs and HCC patients were higher in Cir patients $(p<0.05)$, and IL-10 mRNA in ACs was higher than in $\mathrm{ACH}$ patients $(p<0.05)$. These results showed that INF- $\gamma$ mRNA, IL-6 mRNA and IL-18 mRNA in all five groups stayed unchanged, but that IL-10 mRNA increased in ACs and HCC patients.

Correlations between ALT and costimulatory proteins and between costimulatory proteins in four groups

To identify the effects of costimulation on CHB, we assessed the correlation coefficient between intrahepatic costimulation profiles and serum ALT (see Table 4). The ACH patients showed positive correlations between ALT and inflammatory costimulatory proteins CD80, CD83, CD28, CD40 and ICAM-1 $(p<0.05)$, but negative correlations between CTLA-4 and inflammatory costimulatory proteins CD80, CD86, CD83, CD28, CD40 and ICAM-1 $(p<0.05)$. In AC patients, CTLA-4 was negatively correlated with ALT, CD83, CD40 and ICAM-1 $(p<0.05)$, and IL-10 mRNA was negatively correlated with ALT $(p<0.05)$. Interestingly, ALT was positively correlated with CD80, CD86, CD83, CD28, CD40 and ICAM-1 $(p<0.05)$, although ALT was below the upper limit of normal in all six ACs. A positive correlation between ALT 
Table 4 Pairwise correlation between ALT and costimulatory proteins, or between CTLA-4 and other costimulatory proteins

\begin{tabular}{|c|c|c|c|c|c|c|c|c|c|}
\hline & ALT & CD80 & CD86 & CD83 & CD28 & CTLA-4 & $\mathrm{CD} 40$ & ICAM-1 & IL-10 mRNA \\
\hline \multicolumn{10}{|l|}{ ALT } \\
\hline \multirow[t]{2}{*}{ AC group } & $R: 1$ & $0.756^{*}$ & $0.878^{*}$ & $0.889^{*}$ & $0.737 *$ & $-0.855^{*}$ & $0.914 *$ & $0.922^{*}$ & $-0.909 *$ \\
\hline & $p:$ & 0.041 & 0.01 & 0.009 & 0.047 & 0.015 & 0.005 & 0.004 & 0.006 \\
\hline \multirow[t]{2}{*}{$\mathrm{ACH}$ group } & $R: 1$ & $0.807 *$ & 0.684 & $0.859^{*}$ & $0.890 *$ & -0.643 & $0.850 *$ & $0.738^{*}$ & -0.528 \\
\hline & $p:$ & 0.026 & 0.067 & 0.014 & 0.009 & 0.084 & 0.016 & 0.047 & 0.141 \\
\hline \multirow[t]{2}{*}{ Cir group } & $R: 1$ & $0.972 *$ & 0.028 & 0.200 & -0.080 & -0.522 & 0.311 & -0.256 & 0.678 \\
\hline & $p:$ & 0.001 & 0.958 & 0.704 & 0.881 & 0.288 & 0.549 & 0.625 & 0.069 \\
\hline \multirow[t]{2}{*}{ HCC group } & $R: 1$ & 0.115 & 0.577 & 0.301 & 0.614 & 0.267 & -0.432 & -0.586 & $-0.752^{*}$ \\
\hline & $p:$ & 0.826 & 0.231 & 0.562 & 0.194 & 0.609 & 0.393 & 0.222 & 0.042 \\
\hline \multicolumn{10}{|l|}{ CTLA-4 } \\
\hline \multirow[t]{2}{*}{ AC group } & $R:-0.855$ & -0.426 & -0.675 & $-0.776^{*}$ & -0.421 & 1 & $-0.842 *$ & $-0.831^{*}$ & \\
\hline & $* p: 0.015$ & 0.200 & 0.071 & 0.035 & 0.203 & & 0.018 & 0.02 & \\
\hline \multirow[t]{2}{*}{$\mathrm{ACH}$ group } & $R:-0.643$ & $-0.821^{*}$ & $-0.961 *$ & $-0.903^{*}$ & $-0.908 *$ & 1 & $-0.925^{*}$ & $-0.948^{*}$ & \\
\hline & $p: 0.084$ & 0.022 & 0.001 & 0.007 & 0.006 & & 0.004 & 0.002 & \\
\hline \multirow[t]{2}{*}{ Cir group } & $R:-0.522$ & -0.646 & -0.682 & -0.341 & 0.585 & 1 & 0.193 & -0.590 & \\
\hline & $p: 0.288$ & 0.166 & 0.135 & 0.508 & 0.222 & & 0.714 & 0.217 & \\
\hline \multirow[t]{2}{*}{ HCC group } & $R: 0.267$ & -0.339 & 0.423 & $0.978^{*}$ & 0.592 & 1 & -0.559 & 0.350 & \\
\hline & $p: 0.609$ & 0.511 & 0.404 & 0.001 & 0.216 & & 0.249 & 0.496 & \\
\hline
\end{tabular}

$* p<0.05$

and CD80 $(p<0.05)$ was present in the Cir patients. In addition, a negative correlation between ALT and IL-10 mRNA and a positive correlation between CTLA-4 and CD83 $(p<0.05)$ were displayed in the HCC patients. These results indicate that both increased inflammatory costimulatory proteins and decreased inhibitory costimulatory proteins participated in hepatitis activation in $\mathrm{ACH}$ patients, and that inhibitory costimulatory proteins CTLA4 and IL-10 contributed to immune tolerance and maintained normal hepatic function in ACs.

\section{Discussion}

Costimulatory factors participate in immune responses to HBV components, and induce maturation of DCs, activation of $\mathrm{T}$ cells and other immune cells, and secretion of cytokines. Overall, the intrahepatic costimulation profile represents opposing immunocompetences, either inflammatory or suppressive immune responses, which characterize the actual immunopathophysiology of $\mathrm{CHB}$ [7, 22, 24]. Our data showed decreased CTLA-4 and IL-10 and increased CD80, CD86, CD83, CD28, CD40 and ICAM-1 in the liver of ACH patients. In contrast, a special costimulatory expression, namely increased inhibitory costimulatory factors and decreased inflammatory costimulatory proteins, presented in the ACs. However, the costimulation profiles in the $\mathrm{Cir}$ and HCC patients were confusing. An inconsistent expression of costimulatory factors, namely increased expression of both inhibitory and inflammatory costimulatory factors, occurred in the Cir patients. In contrast, decreased expression of both inhibitory and inflammatory costimulatory factors was present in the HCC patients. The CHB patients presented various costimulation profiles in liver.

Previous investigations and the present study both demonstrated that intrahepatic costimulation profiles contributed to immunopathogenesis in $\mathrm{CHB}$ patients. Chen et al. and Zou et al. [25, 26] investigated intrahepatic IL$10, \mathrm{INF}-\gamma$ or programmed death 1 (PD-1) receptors in $\mathrm{CHB}$ patients using immunohistochemistry and assessed the correlation between the immunohistochemical intensity in liver and ALT in serum. Stoop et al. [14] observed intrahepatic regulatory $\mathrm{T}$ cells using flow cytometry and evaluated the role of these cells using correlation analysis. Using immunohistochemistry and histology, we observed the distribution of costimulatory proteins and necroinflammation scores in liver to be consistent with previous studies. The cells with positive inflammatory costimulatory proteins were localized in the necroinflammatory zone in the liver of $\mathrm{ACH}$ and Cir patients. We therefore considered that various inflammatory cells participate in the immunopathogenesis of $\mathrm{CHB}$ by regulating costimulatory proteins. In addition, intrahepatic costimulation profiles were quantitatively detected using Western blotting, and the relationship between the intrahepatic costimulation 
profile and serum ALT was assessed in the present study. The results demonstrated that increased inflammatory costimulation and decreased inhibitory costimulation both contributed to intrahepatic necroinflammation and caused abnormal hepatic function in $\mathrm{ACH}$ patients. In contrast, increased inhibitory costimulation and decreased inflammatory costimulation in ACs resulted in no intrahepatic necroinflammation and in normal serum ALT, representing immune tolerance. However, the costimulation profiles in the Cir and HCC patients were puzzling, and we were not able to explain the associations in the costimulation profiles. Our data further revealed that the intrahepatic costimulation profiles, instead of a single costimulatory factor, contributed to immunopathogenesis in CHB patients and resulted in multiple abnormalities in immune response pathways, including DC maturation, immune cell activation and cytokine secretion.

In Asia, the majority of $\mathrm{HBV}$ infection is acquired perinatally or in early childhood; a large number of patients are therefore in the immune-tolerant phase [2]. Because of the lack of a suitable animal model for the investigation of the immune state of CHB patients, almost nothing is known about the mechanism of immune tolerance and the differences between immune tolerance and immune injury. The immune tolerance of CHB patien is still a mysterious phenomenon. In the present study, the differences between costimulation profiles in the liver of ACs and those of the $\mathrm{ACH}$, Cir and HCC patients were shown for the first time, revealing some of the characteristics of immune tolerance.

Notably, opposite CTLA-4 expressions were present in ACs and HCC patients, namely increased CTLA-4 in the ACs and decreased CTLA- 4 in the HCC patients. CTLA-4 and PD-1 inhibit T-cell activation through different pathways: PD-1 inhibits CD28-mediated activation of phosphatidylinositol 3-kinase (PI3K), whereas CTLA-4 activates type II serine/threonine phosphatase PP2A. Both CTLA-4 and PD-1 limit T-cell activation [27]. In a study by Nakamoto et al., CD28 was highly expressed in intrahepatic PD $-1^{+}$CTLA- $4^{+}$CD8 $\mathrm{T}$ cells compared to CTLA$4^{-}$CD8 T cells, and increased CD28 is a marker of T-cell activation. By competing with CD28 for CD80 and CD86, CTLA-4 may inhibit CD28 ${ }^{+}$T-cell activation by specific signaling pathways. Interestingly, CTLA-4 may play different roles in various signaling pathways in viral infections, such as lymphocytic choriomeningitis virus, human immunodeficiency virus and hepatitis $C$ virus [16]. The above studies lead us to speculate that these opposing CTLA-4 expressions in ACs and HCC patients might result from various CTLA-4 signaling pathways for immune tolerance of $\mathrm{T}$ cells or generation of HCC. However, the mechanism remains unknown.

The present study was an observational investigation of human liver. We would like to improve the work by investigating further cases or by performing more techniques. However, ethical principles in the clinical study limited the acquisition of human tissue. In previous clinical investigations, a single immunological technique was applied to exploring intrahepatic immunopathogenesis in CHB patients, such as immunohistochemistry in studies by Chen et al. and Zou et al. [25, 26] or flow cytometry in Stoop et al. [14]. However, immunohistochemical pathologists, such as Becker and Taylor [28], believe that immunohistochemistry-based methods retain morphological data but prove difficult to quantify, and that Western blotting may be used for quantitative detection of protein in tissue. In a study by Philips et al., both Western blotting and immunohistochemistry were used to investigate enzyme proteins in the human bladder [29]. According to Becker's strategy and Phillips' measurements, we applied two techniques, immunohistochemistry and Western blotting, to explore the effects of costimulatory proteins in liver. A limit of 6 liver specimens from each group was used in the present study, which followed both ethical principles and statistical principles in an observational investigation of human tissue. In addition, we wish to further explore the mechanism of immune tolerance and immune injury on costimulation using analysis of signal pathways. However, this intent is merely a wish because a suitable animal model with the whole disease spectrum of CHB has not been established and perfect human specimens for investigation of signal pathways cannot be obtained. For the first time, the profiles of intrahepatic costimulation in CHB patients were investigated here, which revealed the natural immune status of the patients. A prominent feature of the present study was that the human liver with the whole disease spectrum of CHB, instead of cell culture in vitro or intervening analysis in an animal model, was applied to investigate immunopathophysiology. Despite the present study being preliminary, the findings are groundbreaking in the field of chronic HBV infection.

In conclusion, various profiles of costimulation are present in the liver of CHB patients. Costimulation participates in immune responses in liver and plays important roles in immune tolerance in ACs, in immune injury in $\mathrm{ACH}$ patients and in immune abnormalities in $\mathrm{Cir}$ and HCC patients. The multiple abnormalities in the immune response create the immunopathogenesis of CHB patients.

Acknowledgments The authors thank Dr. Ming Ma, Dr. Hao Duanmu and Dr. Hai Ding of the Second Affiliated Hospital, Southeast University Medical School, Dr. Yufeng Li of the First People's Hospital of Huai' an City and Dr. Yijun Chen of the People's Hospital of Tai'xing City and Dr. Sen Lu of the Liver Transplantation Center of the First Affiliated Hospital, Nanjing Medical University for liver biopsy sample or liver sample procurement, and $\mathrm{PhD}$ Jiawen Yin, Dr. Haiying Ma and Quan Yang for technical assistance. We are grateful for language editing of the manuscript by Prof Feirong $\mathrm{Gu}$ of the College of Foreign Studies, Nanjing Agricultural University. 
This work was supported by ZKX(0102)/the Government of Nanjing City and TS(9904)/the Health Office of Jiangsu Provincial Government.

Conflict of interest The authors declare no financial or commercial conflict of interest.

Open Access This article is distributed under the terms of the Creative Commons Attribution License which permits any use, distribution, and reproduction in any medium, provided the original author(s) and the source are credited.

\section{References}

1. European Association for the Study of the Liver. EASL clinical practice guidelines: management of chronic hepatitis B virus infection. J Hepatol. 2012;57:167-85.

2. Liaw YF, Leung N, Kao JH, Piratvisuth T, Gane E, Han KH, et al. Asian-Pacific consensus statement on the management of chronic hepatitis B. Hepatol Int. 2008;2:263-83.

3. Zhang Z, Zhang JY, Wang LF, Wang FS. Immunopathogenesis and prognostic immune markers of chronic hepatitis $B$ virus infection. J Gastroenterol Hepatol. 2012;27:223-30.

4. Op den Brouw ML, Binda RS, van Roosmalen MH, Protzer U, Janssen HL, van der Molen RG, et al. Hepatitis B virus surface antigen impairs myeloid dendritic cell function: a possible immune escape mechanism of hepatitis B virus. Immunology. 2009;126:280-9.

5. Beckebaum S, Cicinnati VR, Dworacki G, Müller-Berghaus J, Stolz D, Harnaha J, et al. Reduction in the circulating pDC1/ pDC2 ratio and impaired function of ex vivo-generated DC1 in chronic hepatitis B infection. Clin Immunol. 2002;104:138-50.

6. Zheng X, Zhang H, Yin L, Wang CR, Liu Y, Zheng P. Modulation of NKT cell development by B7-CD28 interaction: an expanding horizon for costimulation. PLoS One. 2008;16(3):e2703.

7. Kunitani H, Shimizu Y, Murata H, Higuchi K, Watanabe A. Phenotypic analysis of circulating and intrahepatic dendritic cell subsets in patients with chronic liver diseases. J Hepatol. 2002;36:734-41.

8. Fujiwara K, Higashi T, Nouso K, Nakatsukasa H, Kobayashi Y, Uemura $\mathrm{M}$, et al. Decreased expression of B7 costimulatory molecules and major histocompatibility complex class-I in human hepatocellular carcinoma. J Gastroenterol Hepatol. 2004;19:1121-7.

9. Barboza L, Salmen S, Peterson DL, Montes H, Colmenares M, Hernández $\mathrm{M}$, et al. Altered $\mathrm{T}$ cell costimulation during chronic hepatitis B infection. Cell Immunol. 2009;257:61-8.

10. Kennedy PT, Sandalova E, Jo J, Gill U, Ushiro-Lumb I, Tan AT, et al. Preserved T-cell function in children and young adults with immune-tolerant chronic hepatitis B. Gastroenterology. 2012;143:637-45.

11. Xia S, Guo Z, Xu X, Yi H, Wang Q, Cao X. Hepatic microenvironment programs hematopoietic progenitor differentiation into regulatory dendritic cells, maintaining liver tolerance. Blood. 2008;112:3175-85.

12. Loirat D, Mancini-Bourgine M, Abastado JP, Michel ML. HBsAg/HLA-A2 transgenic mice: a model for T cell tolerance to hepatitis B surface antigen in chronic hepatitis B virus infection. Int Immunol. 2003;15:1125-36.

13. Maier H, Isogawa M, Freeman GJ, Chisari FV. PD-1: PD-L1 interactions contribute to the functional suppression of virus- specific CD8+ T lymphocytes in the liver. J Immunol. 2007;178: 2714-20.

14. Stoop JN, Claassen MA, Woltman AM, Binda RS, Kuipers EJ, Janssen HL, et al. Intrahepatic regulatory $\mathrm{T}$ cells are phenotypically distinct from their peripheral counterparts in chronic HBV patients. Clin Immunol. 2008;129:419-27.

15. Roger PM, Chaillou S, Breittmayer JP, Dahman M, St Paul MC, Chevallier P, et al. Intrahepatic CD4 T-Cell apoptosis is related to METAVIR score in patients with chronic hepatitis $\mathrm{C}$ virus. Scand J Immunol. 2005;62:168-75.

16. Nakamoto N, Cho H, Shaked A, Olthoff K, Valiga ME, Kaminski $\mathrm{M}$, et al. Synergistic reversal of intrahepatic HCV-specific CD8 T cell exhaustion by combined PD-1/CTLA-4 blockade. PLoS Pathog. 2009;5(2):e1000313.

17. Lok AS, McMahon BJ. Chronic hepatitis B. Hepatology. 2001;34:1225-41.

18. Zhong B, Ma HY, Yang Q, Gu FR, Yin GQ, Xia CM. Decrease in toll-like receptors 2 and 4 in the spleen of mouse with endotoxic tolerance. Inflamm Res. 2008;57:252-9.

19. Brunt EM. Grading and staging the histopathological lesions of chronic hepatitis: the Knodell histology activity index and beyond. Hepatology. 2000;31:241-6.

20. Gong AY, Zhou R, Hu G, Li X, Splinter PL, O'Hara SP, et al. MicroRNA-513 regulates B7-H1 translation and is involved in IFN-gamma-induced B7-H1 expression in cholangiocytes. J Immunol. 2009;182:1325-33.

21. Alegre ML, Frauwirth KA, Thompson CB. T-cell regulation by CD28 and CTLA-4. Nat Rev Immunol. 2001;1:220-8.

22. Chen K, Huang J, Gong W, Zhang L, Yu P, Wang JM. CD40/ CD40L dyad in the inflammatory and immune responses in the central nervous system. Cell Mol Immunol. 2006;3:163-9.

23. Muhanna N, Doron S, Wald O, Horani A, Eid A, Pappo O, et al. Activation of hepatic stellate cells after phagocytosis of lymphocytes: a novel pathway of fibrogenesis. Hepatology. 2008;48:963-77.

24. Tu Z, Pierce RH, Kurtis J, Kuroki Y, Crispe IN, Orloff MS. Hepatitis $\mathrm{C}$ virus core protein subverts the antiviral activities of human Kupffer cells. Gastroenterology. 2010;138:305-14.

25. Chen J, Wang XM, Wu XJ, Wang Y, Zhao H, Shen B, et al. Intrahepatic levels of PD-1/PD-L correlate with liver inflammation in chronic hepatitis B. Inflamm Res. 2011;60(1):47-53.

26. Zou Z, Li B, Xu D, Zhang Z, Zhao JM, Zhou G, et al. Imbalanced intrahepatic cytokine expression of interferon-gamma, tumor necrosis factor-alpha, and interleukin-10 in patients with acuteon-chronic liver failure associated with hepatitis B virus infection. J Clin Gastroenterol. 2009;43:182-90.

27. Parry RV, Chemnitz JM, Frauwirth KA, Lanfranco AR, Braunstein I, Kobayashi SV, et al. CTLA-4 and PD-1 receptors inhibit T-cell activation by distinct mechanisms. Mol Cell Biol. 2005;25:9543-53.

28. Becker KF, Taylor CR. "Liquid morphology": immunochemical analysis of proteins extracted from formalin-fixed paraffinembedded tissues: combining proteomics with immunohistochemistry. Appl Immunohistochem Mol Morphol. 2011;19:1-9.

29. Philips BJ, Dhir R, Hutzley J, Sen M, Kelavkar UP. Polyunsaturated fatty acid metabolizing 15-lipoxygenase-1 (15-LO-1) expression in normal and tumorigenic human bladder tissues. Appl Immunohistochem Mol Morphol. 2008;16:159-64.

30. Tripathy AS, Das R, Chadha MS, Arankalle VA. Epidemic of hepatitis B with high mortality in India: association of fulminant disease with lack of CCL4 and natural killer T cells. J Viral Hepat. 2011;18:e415-22. 